\title{
BRITISH HISTORICAL FACTS
}

1760-1830 
Other titles already published in this series

ENglish historical facts 1485-1603 (Ken Powell and Chris Cook) BRITISH HISTORICAL FACTS 1830-1900 (Chris Cook and Brendan Keith) European Political facts 1848-1918 (Chris Cook and John Paxton) european political facts 1918-1973 (Chris Cook and John Paxton)

Also by Chris Cook and John Stevenson

THE SLUMP: SOCIETY AND POLITICS DURING THE DEPRESSION THE LONGMAN ATLAS OF MODERN BRITISH HISTORY 1700-1970

THE ATLAS OF MODERN WARFARE

Other books by Chris Cook

THE AGE OF ALIGNMENT: ELECTORAL POLITICS IN BRITAIN 1922-1929

A SHORT HISTORY OF THE LIBERAL PARTY 1900-1976

BY-ELEGTIONS IN BRITISH POLITICS (ed. with John Ramsden)

THE POLITICS OF REAPpraisal 1918-1939 (ed. with Gillian Peele)

THE DECADE OF DISILlusion (ed. with David McKie)

CRISIS AND CONTROVERSY: ESSAYS IN HONOUR OF A. J. P. TAYLOR (ed. with Alan Sked) SOURCES IN BRITISH POLITICAL HISTORY 1900-1951 (with Philip Jones et al.)

Other books by John Stevenson

SOCIAL CONDITIONS IN BRITAIN BETWEEN THE WARS

POPULAR DISTURBANCES IN ENGLAND 1700-1870

LONDON IN THE AGE OF REFORM

POPULAR PROTEST AND PUBLIC ORDER (ed. with $R$. Quinault)

Other titles in preparation in this series

ENGLISH HISTORICAL FACTS 1603-1688 (Chris Cook and John Wroughton) EURopean POLITICAL facts 1789-1848 (Chris Cook and John Paxton) 


\section{B RITISH \\ HISTORICAL FACTS \\ 1760-1830}

CHRIS COOK

AND

JOHN STEVENSON 


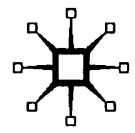

(c) Chris Cook and John Stevenson 1980

Softcover reprint of the hardcover 1st edition 1980 978-0-333-21512-8

All rights reserved. No reproduction, copy or transmission of this publication may be made without written permission.

No paragraph of this publication may be reproduced, copied or transmitted save with written permission or in accordance with the provisions of the Copyright, Designs and Patents Act 1988, or under the terms of any licence permitting limited copying issued by the Copyright Licensing Agency, 90 Tottenham Court Road, London W1P OLP.

Any person who does any unauthorised act in relation to this publication may be liable to criminal prosecution and civil claims for damages.

The authors have asserted their rights to be identified as the authors of this work in accordance with the Copyright, Designs and Patents Act 1988.

Published by

PALGRAVE

Houndmills, Basingstoke, Hampshire RG21 6XS and 175 Fifth Avenue, New York, N. Y. 10010

Companies and representatives throughout the world

PALGRAVE is the new global academic imprint of St. Martin's Press LLC Scholarly and Reference Division and Palgrave Publishers Ltd (formerly Macmillan Press Ltd).

ISBN 978-1-349-63687-7 ISBN 978-1-137-06465-3 (eBook)

DOI 10.1007/978-1-137-06465-3

This book is printed on paper suitable for recycling and made from fully managed and sustained forest sources.

A catalogue record for this book is available from the British Library.

Transferred to digital printing 2001 


\section{Contents}

ACKNOWLEDGEMENTS

\section{THE MONARCHY}

Biographical Details of Monarchs and their Issue

Allowances to Members of the Royal Family 3

Grants in One Sum to Members of the

Royal Family, 1760-1820

Regnal Years, 1760-1830

Office-holders of the Household

2. MINISTRIES AND ADMINISTRATIONS

Chronological List 11

Composition of Each Ministry 11

$\begin{array}{ll}\text { Biographical Details of Major Ministers } & 20\end{array}$

3. SELECTED HOLDERS OF PUBLIC OFFICE

Offices 26

Holders

4. THE PEERAGE AND ORDERS OF KNIGHTHOOD

Creations and Promotions within the

Higher Peerage

The Orders of Knighthood $\quad 40$

Order of the Garter: Creations, 1760-1830 40

Order of the Thistle $\quad 42$

Order of the Bath 43

Order of St Patrick $\quad 45$

Order of St Michael and St George $\quad 46$

5. PARLIAMENT AND ELEGTIONS

House of Commons $\quad 47$

Speakers $\quad 47$

Contested Elections for the Speakership $\quad 47$

Chairmen of Ways and Means 47

Clerks of the House 47

Parliamentary Sessions $\quad 48$

Composition of the House 48

Public Petitions $\quad 49$

Social Status of Members $\quad 49$

House of Lords 
Lord Chairmen of Committees 49

Officers $\quad 50$

Composition of the House $\quad 50$

Party Leaders, 1783-1830 50

Scottish Representative Peers 51

Irish Representative Peers $\quad 52$

The Franchise $\quad 53$

$\begin{array}{ll}\text { Patronage } & 59\end{array}$

6. FOREIGN AFFAIRS

British Treaties, 1756-1830 60

Principal British Diplomatic Representatives, 1760-1830 70

International Conferences and Congresses, $\begin{array}{ll}1800-30 & 79\end{array}$

7. THE ARMED FORCES

Outlines of British Campaigns, 1755-1830 80

Principal Battles, 1755-1830 92

Strength and Cost of the Army, 1755-1830 97

Loans and Subsidies to Foreign States during the Wars of 1793-1814 99

Annual Parliamentary Votes for the Navy, 1755-1830 101

$\begin{array}{ll}\text { Military Office-holders } & 102\end{array}$

Biographical Details of Major Commanders, 1755-1830 103

Bibliography 111

8. THE EMPIRE AND INDIA

Main Territories under British Rule by $1830 \quad 113$

$\begin{array}{ll}\text { The American Colonies } & 113\end{array}$

Major Events in Irish History 115

$\begin{array}{ll}\text { Holders of Important Office concerned } & 120 \\ \text { with India } & 121\end{array}$

$\begin{array}{ll}\text { Colonial Governors } & 121\end{array}$

9. RADICALISM, TRADE UNIONS AND POLITICAL REFORM

$\begin{array}{ll}\text { Trade Unions } & 128\end{array}$

$\begin{array}{ll}\text { Chronology of Trade Union } & 128\end{array}$

The Combination Acts $\quad 129$

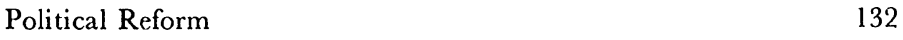

$\begin{array}{ll}\text { The Parliamentary Reform Movement, } & \\ 1760-1829 & 132\end{array}$

The Reform Crisis, 1830-2 136

Major Reform Societies and Clubs $\quad 137$

Biographical Details of Major

Reformers 140 
10. LAW AND ORDER

Principal Judges

Major Developments in Public Order

Popular Disturbances in Britain (excluding Ireland) 147

Griminal Statistics

The Abolition of Capital Offences, 1808-30

\section{THE PRESS}

Newspaper Legislation, Taxes and Prices

National Newspaper Press - Chronology of Main Events

Provincial Newspaper Press

Bibliography

\section{RELIGION}

\section{Religious Statistics}

The Ghurch of England 162

The Catholic Church 163

The New Dissent 163

$\begin{array}{ll}\text { The Church of England } & 164\end{array}$

Archbishops and Bishops 164

Plurality and Non-residence 166

Revenues from Bishoprics, $1760 \quad 167$

Missionary and Benevolent Societies $\quad 167$

$\begin{array}{ll}\text { The Clapham Sect } & 168\end{array}$

$\begin{array}{ll}\text { Chronology of the New Dissent } & 168\end{array}$

Protestant Dissenters 168

Methodists 169

$\begin{array}{ll}\text { Baptists } & 169\end{array}$

$\begin{array}{ll}\text { Roman Catholicism } & 170\end{array}$

Popes, with Family Name $\quad 170$

Chronology of Principal Events 170

Main Centres of Roman Catholic Refugees, 1794

Wales

Scotland

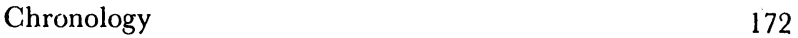

Dioceses of the Episcopal Church 173

$\begin{array}{ll}\text { Primus of Episcopal Church } & 173\end{array}$

Roman Catholics $\quad 173$

$\begin{array}{ll}\text { Ireland } & 174\end{array}$

Chronology 174

Division of Population among Greeds 175

Dioceses of Church of Ireland, 1714-1830 175

13. SELECTED HOLDERS OF LOCAL GOVERNMENT OFFICE

Lord Lieutenants, England

Lord Lieutenants, Wales 
viii GONTENTS

14. THE ECONOMY

Population, 1761-1831 181

Principal Urban Populations, 1801 and 1831

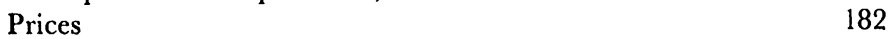

Average Price of Wheat in England and Wales, 1771-1830 182

Industrial Production, 1801-30 183

Raw Cotton Imports and Consumption 183

Enclosure Acts, 1760-1830 184

The Corn Laws $\quad 184$

Trade $\quad 185$

Shipping and Shipbuilding $\quad 185$

Public Income and Expenditure $\quad 186$

The National Debt $\quad 187$

Yield on Consols $\quad 187$

Income Tax: Rates and Yields, 1799-1816 187

Country Banks in England and Wales, 1784-1830 188

Canal Acts, 1759-1827 188

Distribution of the Labour Force, 1801-31 191

15. SOCIAL DEVELOPMENTS

Major Social Legislation and Developments 192

Hospital Foundations, 1714-1830 192

Charities and Philanthropic Societies 193

Education $\quad 194$

Poor Relief, 1783-1831 194

Friendly Societies $\quad 194$

BIBLIOGRAPHICAL NOTE 196 


\section{Acknowledgements}

Like the companion volume in this series, British Historical Facts, 1830-1900, the compilation of this book owes a very large debt to the pioneering efforts of David Butler, whose British Political Facts 1900-1975 provided both the original idea and model for this latest volume. Much work for this book was undertaken at Nuffield College, Oxford. Both authors would like to record their thanks to the Warden and Fellows of the College for making its facilities so readily available.

Inevitably, for a reference work on a period as far back as 1760 to 1830 , there is a difference in emphasis in this volume compared to its companions in the series. Diplomatic and military affairs occupy more space. There are details on the peerage and orders of knighthood that would be inappropriate in later volumes. Inevitably, party politics and electoral statistics cannot be as fully treated, but riots, public order and political reform come to the fore.

No volume of this type can ever hope to be definitive. The editors hope, however, that they have gathered together as many of the most useful facts and figures as can be included within the confines of a medium-sized reference work. Suggestions for additional material to be included in subsequent editions of this book will be welcomed.

Several people have contributed to the compilation of this book. The chapter on the armed forces was compiled by Stephen Brooks. Alan Gilbert and Anthony Bax provided much of the material for the chapter on religion. Jackie Johns gave valued advice on early trade unionism. Amongst others whom we would like to thank are Sheila Fairfield, Philip Riden and Philip Woods.

Finally, a very special debt is due to two people. John Brooke has encouraged the compilation of this book from the outset. His advice and guidance have been greatly appreciated. John Sainty, whose own definitive work on office-holders constitutes a towering achievement of scholarship, has generously given of his time to guide the authors from some, at least, of the pitfalls of compiling a work of reference for this period. 